\title{
Parenteral nutrition solution in cerebrospinal fluid of a neonate: complication from a malpositioned central venous catheter
}

\author{
Ling Chin 조 , Pauline Poh Ling Choo, David CE Ng
}

Pediatrics, Hospital Tuanku Ja'afar Seremban, Seremban, Negeri Sembilan, Malaysia

Correspondence to Dr David CE Ng; davidngce@gmail.com

Accepted 19 October 2021

\section{DESCRIPTION}

A premature infant was delivered at 30 weeks with a birth weight of $1440 \mathrm{~g}$. The infant required intubation at birth for respiratory distress syndrome. On the second day of life, a peripherally inserted central catheter (PICC) was placed via the left saphenous vein for administration of total parenteral nutrition (TPN). The tip of the catheter was thought to be in the lower inferior vena cava from the plain anteroposterior (AP) radiograph (figure 1) and TPN infusion was commenced. Ten days later, the infant developed multiple apneic episodes and became hypotonic. A lumbar puncture was performed as part of the septic workup. The cerebrospinal fluid (CSF) peculiarly appeared milky white (figure 2). Biochemical analysis of the CSF revealed a high concentration of triglycerides $(31.74 \mathrm{mmol} / \mathrm{L})$ and proteins $(1.05 \mathrm{~g} / \mathrm{L})$, suggesting TPN solution in the CSF. Serum triglycerides were normal $(0.57 \mathrm{mmol} / \mathrm{L})$. Blood and CSF cultures were negative. The infant's radiograph was reviewed again, realising the catheter was likely inadvertently

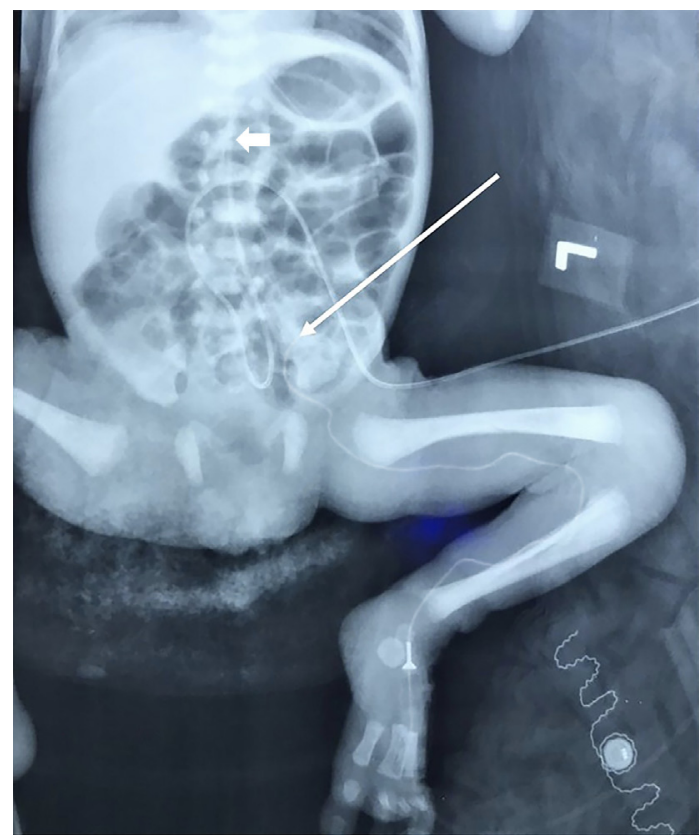

Figure 1 Plain anteroposterior radiograph of the left lower limb and abdomen on day 2 of life. The peripherally inserted central catheter catheter tip location is shown with the thin arrow. The low-lying umbilical vein catheter (thick arrow) was planned for removal as part of the unit's policy.

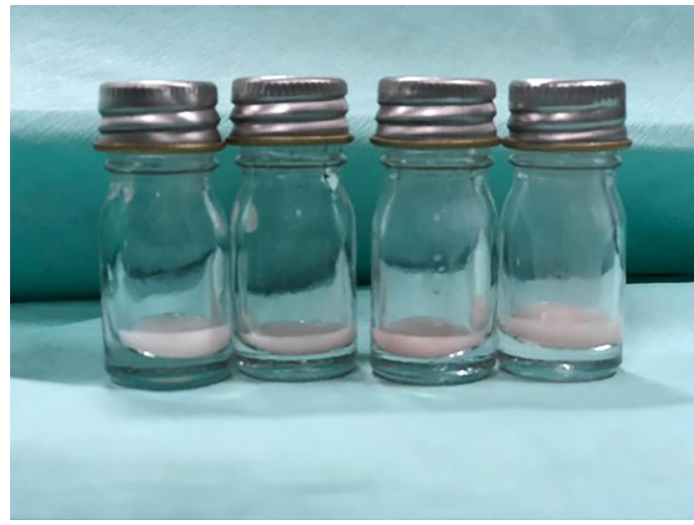

Figure 2 Milk-white cerebrospinal fluid was obtained during lumbar puncture.

placed in the left ascending lumbar vein instead. The infusion of TPN was terminated and the catheter removed, resulting in clinical improvement and resolution of the neurological symptoms. The infant had an uneventful recovery with no neurological sequelae.

Percutaneously inserted central venous lines are an essential part of the care of critically ill and premature neonates, allowing delivery of IV fluids and medication. Although PICC insertions are usually a safe and effective way to secure central venous access, serious complications could occur. TPN fluid leakage into the CSF is an unusual complication from a PICC insertion. ${ }^{12}$ Since the ascending

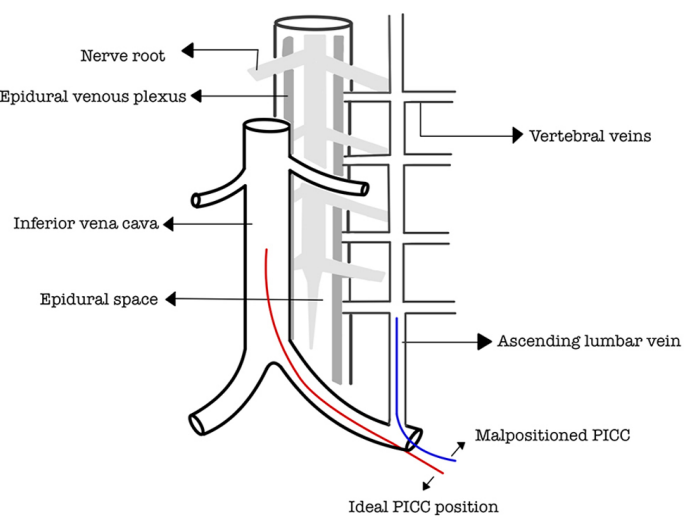

Figure 3 Schematic showing the relationship between the ascending lumbar vein, epidural venous plexus and epidural space. The malpositioned PICC is shown in contrast to its ideal position. PICC, peripherally inserted central catheter. 
lumbar vein drains the epidural venous plexus into the common iliac vein, a PICC tip in the ascending lumbar vein could result in TPN entering the epidural venous plexus (figure 3 ). The hyperosmolar TPN infiltrates the thin-walled epidural veins, leading to extravasation of TPN into the epidural space. Additionally, pressure from the infusion pump could exacerbate the passage of TPN into the CSF.

We urge clinicians to recognise this complication arising from a misplaced central catheter. Our case highlights the importance of careful assessment of the catheter tip position. An addition of a lateral radiograph providing two views would be helpful to reduce such complications. ${ }^{3}$ Likewise, ultrasound

\section{Learning points}

- Careful assessment of the position of the central venous catheter tip is vital to prevent serious complications.

- The presence of milky white cerebrospinal fluid (CSF) with elevation in CSF lipids should prompt clinicians to confirm the position of the central venous catheter immediately.

- A lateral radiograph is recommended whenever an abnormal catheter position is suspected clinically or from findings of routine anteroposterior radiography. guidance may improve procedural success and safety for PICC placement. $^{4}$

Contributors $\mathrm{LC}$ conceptualised the manuscript. LC drafted the first version of the manuscript. PPLC and DCEN revised and added intellectual content. LC, PPLC, DCEN participated in the clinical care of the patient. All authors have read and agreed to the published version of the manuscript.

Funding The authors have not declared a specific grant for this research from any funding agency in the public, commercial or not-for-profit sectors.

Competing interests None declared.

Patient consent for publication Consent obtained from parent(s)/guardian(s)

Provenance and peer review Not commissioned; externally peer reviewed.

\section{ORCID iDs}

Ling Chin http://orcid.org/0000-0002-6591-8483

David CE Ng http://orcid.org/0000-0001-9665-3054

\section{REFERENCES}

1 Lachowska M, Lachowski K, Królak-Olejnik B. Parenteral nutrition solution in cerebrospinal fluid in preterm newborn - a case report and review of the literature. J Vasc Access 2016;17:e82-4.

2 Clarke P, Wadhawan R, Smyth J, et al. Parenteral nutrition solution retrieved by lumbar puncture following left saphenous vein catheterization. J Paediatr Child Health 2003;39:386-9

3 Coit AK, Kamitsuka MD, Pediatrix Medical G, Pediatrix Medical Group. Peripherally inserted central catheter using the saphenous vein: importance of two-view radiographs to determine the tip location. J Perinatol 2005;25:674-6.

4 Fraga MV, Stoller JZ, Glau CL, et al. Seeing is believing: ultrasound in pediatric procedural performance. Pediatrics 2019;144:e20191401.

Copyright 2021 BMJ Publishing Group. All rights reserved. For permission to reuse any of this content visit https://www.bmj.com/company/products-services/rights-and-licensing/permissions/

BMJ Case Report Fellows may re-use this article for personal use and teaching without any further permission.

Become a Fellow of BMJ Case Reports today and you can:

- Submit as many cases as you like

- Enjoy fast sympathetic peer review and rapid publication of accepted articles

- Access all the published articles

Re-use any of the published material for personal use and teaching without further permission

Customer Service

If you have any further queries about your subscription, please contact our customer services team on +44 (0) 2071111105 or via email at support@bmj.com.

Visit casereports.bmj.com for more articles like this and to become a Fellow 